\title{
Раціональне використання
}

геотермальної енергії нафтогазових сверАловин за їх Ауальної експиуатації

Rational use of oil and gas wells geothermal energy for their dual operation

ETAП 2. ПОАІПШЕННЯ ГЕОМЕТРIÏ ТЕХНОЛОГІЙ ГЕОТЕРМААЬНИХ ТЕП^ООБМІННИКІВ В НАФТОГАЗОВИХ СВЕРАЯОВИНАХ 


\section{Вступ Introduction}

- Перше використання 1904 р. в Аардерел^о (Італія)

2019 р. в світі генерується потужність електрики 15 ГВт:

- В т.ч. США - 3,5 ; ІнАОНезія - 2 ; Філіппіни - 1,8

- Переваги теплового енергоресурсу в налрах:

- Невичерпність, стабільність, компактність по площі, екологічність, МожАивість паралельного виАобування інших ресурсї та корисних копалин.
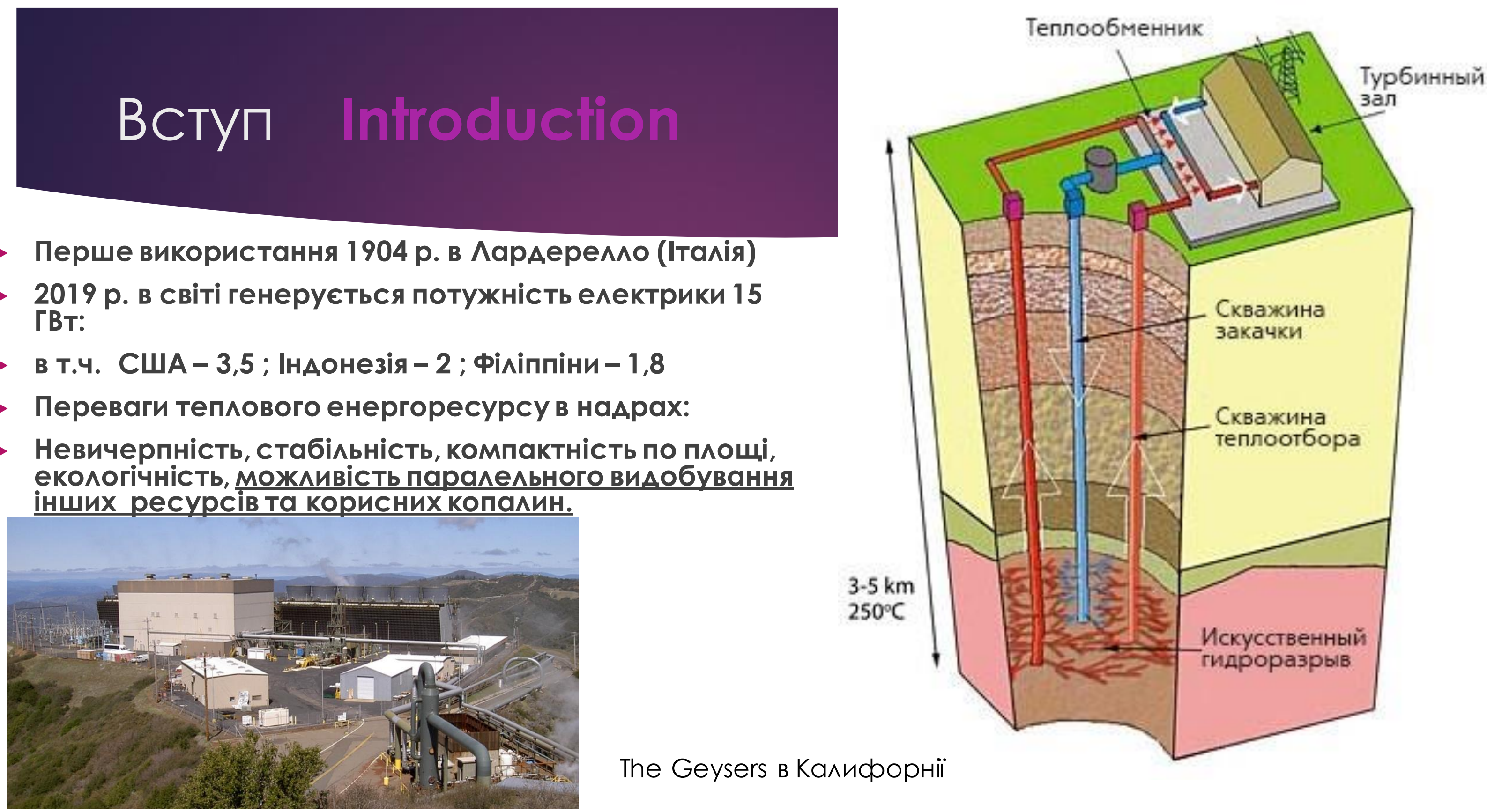


\section{Анотація}

\section{Annotation}

- Використання СверАловин виснажених РОАОвищ МОЖе бУТИ КОМПАЕКСНИМ, КОАИ ОАНОЧवСНО ВИАОбУваЮТЬСЯ ЗаАИШКИ ПРИРОАНИХ ВУГАЕВОАНіВ та геотермальна енергія. При цьому геотермальна енергія може бути використаною не тільки А^я госпоАарських потреб, а й А^я інтенсифікації виАобування і зберігання нафтогазового фАюїАу, виАобуте вуглевоАневе паливо може покращувати евакуацію геотермальної енергії з налр. У цьому випаАку реалізується когнітивний (суміщении 3 виАобУванням фАюїАу) СИстемотеХнічний піАХіА ОАНОчаСНОГО вАОСКОНалеНня ВИАОбУванНя і зберігання вуглевоАневих ресурсів та виАобування енергії тепла поріА. В Ааній роботі розроблено, показано та аналізуються пропоновані авторами схеми когнітивного (Аульного) використання геотермальних ресурсів та геометричні особливості Аіючих нафтогазових сверАловин.
The use of wells of exhausted deposits can be complex when both natural hydrocarbon residues and geothermal energy are extracted simultaneously. In this case, geothermal energy can be used not only for economic needs, but also for the intensification of the extraction and storage of oil and gas fluids, extracted hydrocarbon fuels can improve the evacuation of geothermal energy from the depths. In this case, a cognitive (combined with fluid extraction) system technology approach is simultaneously improving the extraction and storage of hydrocarbon resources and the extraction of heat energy from rocks. In this paper, the authors proposed schemes for the cognitive use of geothermal resources of existing oil and gas wells have been developed, shown and analyzed. 


\section{Суть та актуальність тематики}

- Старі нафтогазові сверАловини після виснаження нафтогазових роАовищ перевоАять в Геотермальний фонА. Останнім часом виконано багато АосліАжень, що пересліАують мету збіАьшення кіАькості нафтогазових сверАловин, які можуть в поАальшому працювати як геотермальні. Але завершувати розробку нафтогазових роАовищ та виАобувати геотермаАьну енергію МожАиво оАночасно. Питання стало набувати актуальності після оцінки геотермальних ресурсів та виявленні значних запасів та потенціалу в районах нафтогазовиАобування в багатьох країнах Світу. Окремі пари сверАловин (АО 5 км гАибиною, бувшого нафтогазового фонАу) наАають Ао 10 МВт теп^ової, та 300 КВт електричної енергії. Це еквівалентно виАобуванню прироАного газу Авома сверАловинами як палива (11 МВт*ч = 1000 М3) 24000 М3/Аобу. 
- Old oil and gas wells are transferred to the geothermal fund after the depletion of oil and gas fields. Lately, a lot of research has been done to pursue the goal of increasing the number of oil and gas wells that can further operate as geothermal wells. But it is possible to complete the development of oil and gas fields and produce geothermal energy at the same time. The issue became more relevant after the assessment of geothermal resources and the identification of significant reserves and potential in oil and gas production areas in many countries of the world. Separate pairs of wells (up to $5 \mathrm{~km}$ deep, formerly an oil well) provide up to $10 \mathrm{MW}$ of heat and $300 \mathrm{~kW}$ of electricity. This is equivalent to extracting natural gas with two wells as fuel ( $11 \mathrm{MWh}=1000$ m3) at 24,000 m3 / day. 
1.Традиційна та пропонована (з когнитивним принципом) схема бінарної геотермальної теп^оелектростанції (1. нафрта і теп^о) Traditional and proposed (with cognitive principle) scheme of binary geothermal thermal power plant
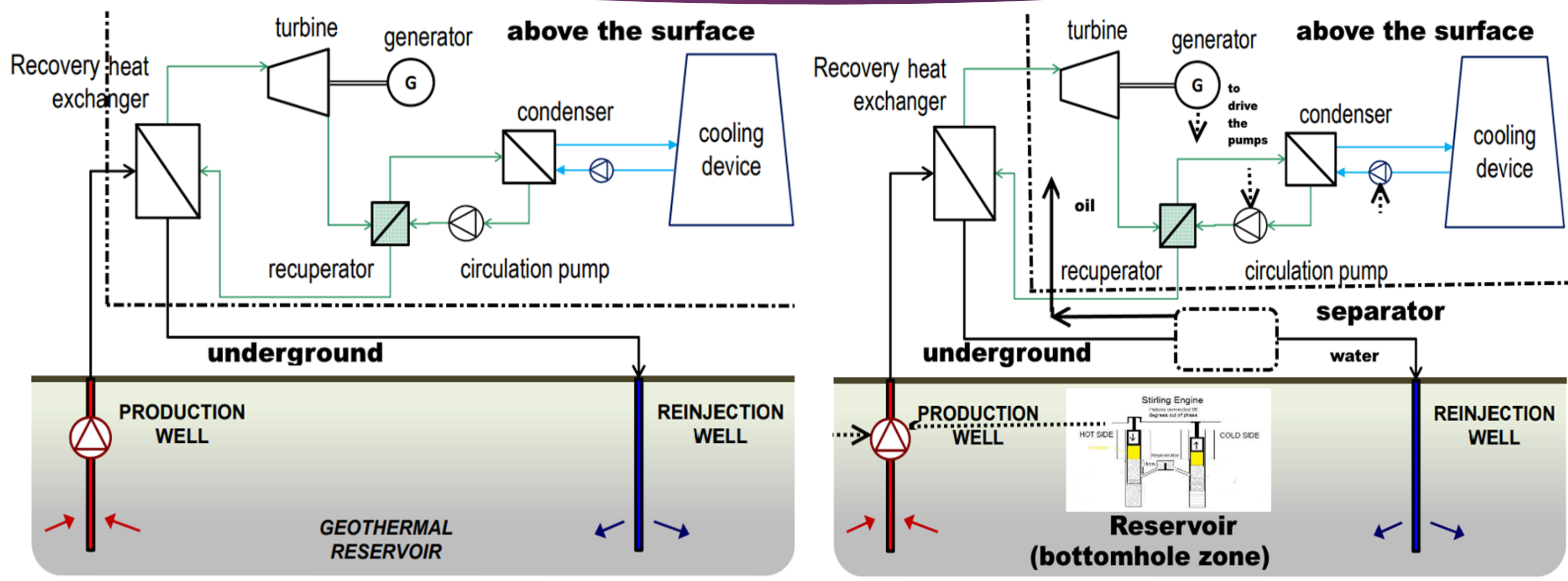
Геометрія вибійного та Аопоміжних геотермальних тепиообмінників в бінарній схемі с гіАротурбіною Geometry of downhole and auxiliory geothermal heat exchangers in binary circuit with hydroulic turbine

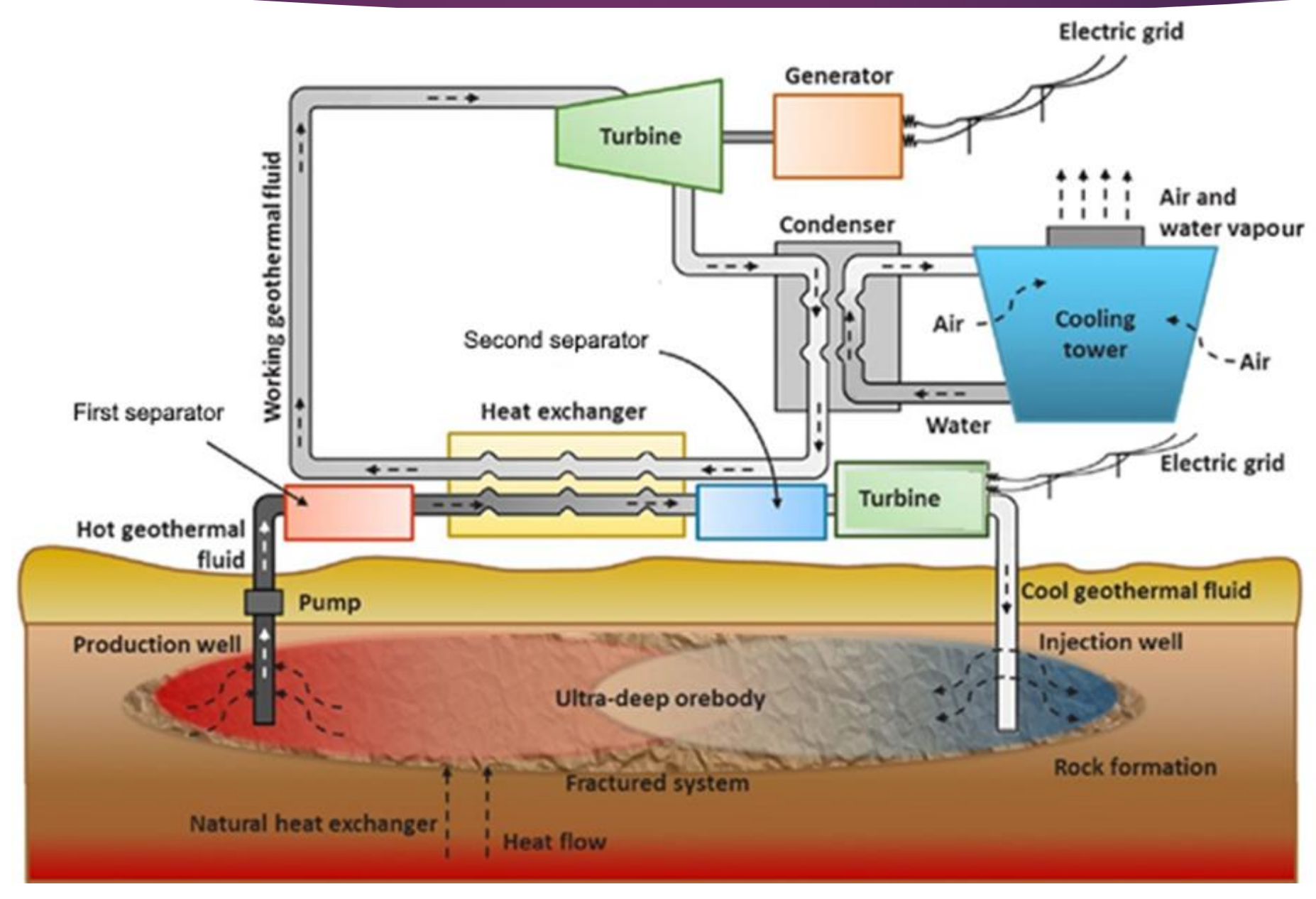




\section{Переваги олночасного (Ауального)}

виАобування ріАКих надртогазових др^юїАів та геотерма^ьного теп^а

- Реалізується зберігання і зменшення втрат наАлишків вилученої теплової енергї у вигАяАі виАОбутих АОАатКовоГо вУгАевоАнів, Синтезі штУчних вуглеводнів, їх закачуванні А^я зберігання;

- - Нівелюються витрати енергії на транспортування вуглеводнево-водного материнського фАюїАу віА зони вибою та у зворотньому напрямку. Транспортується 3 меншими витратами проміжний теплоносій із нанодомішками по трубах сверАловини із спеціальним нанопокриттям;

- - Зменшуються витрати енергії на піАігрів нафти, що піАнімається по проАуктивній колоні сверАловини;

- Розміщення віАкритого контура та теплообмінника цілком у привибійній зоні зменшує втрати теплової енергіі;

- - Зменшення температури у нагнітальній сверАловині збільшує різницю температур між розігрітою сухою породою прилеглих фАюїАоупорів та теп^оносієм, що збільшує притік геотермальної енергії. 


\section{2. Ауальне виАобування вуглеводневого конденсату та теп^а}

Dual hydrocarbon condensate and heat production

У цьому приклаАі показана МоносверАловинна геометрія виАобутку тепла i ріАКих прирОАних вуглевоАнів

This example shows the single well geometry of heat and liquid hydrocarbons

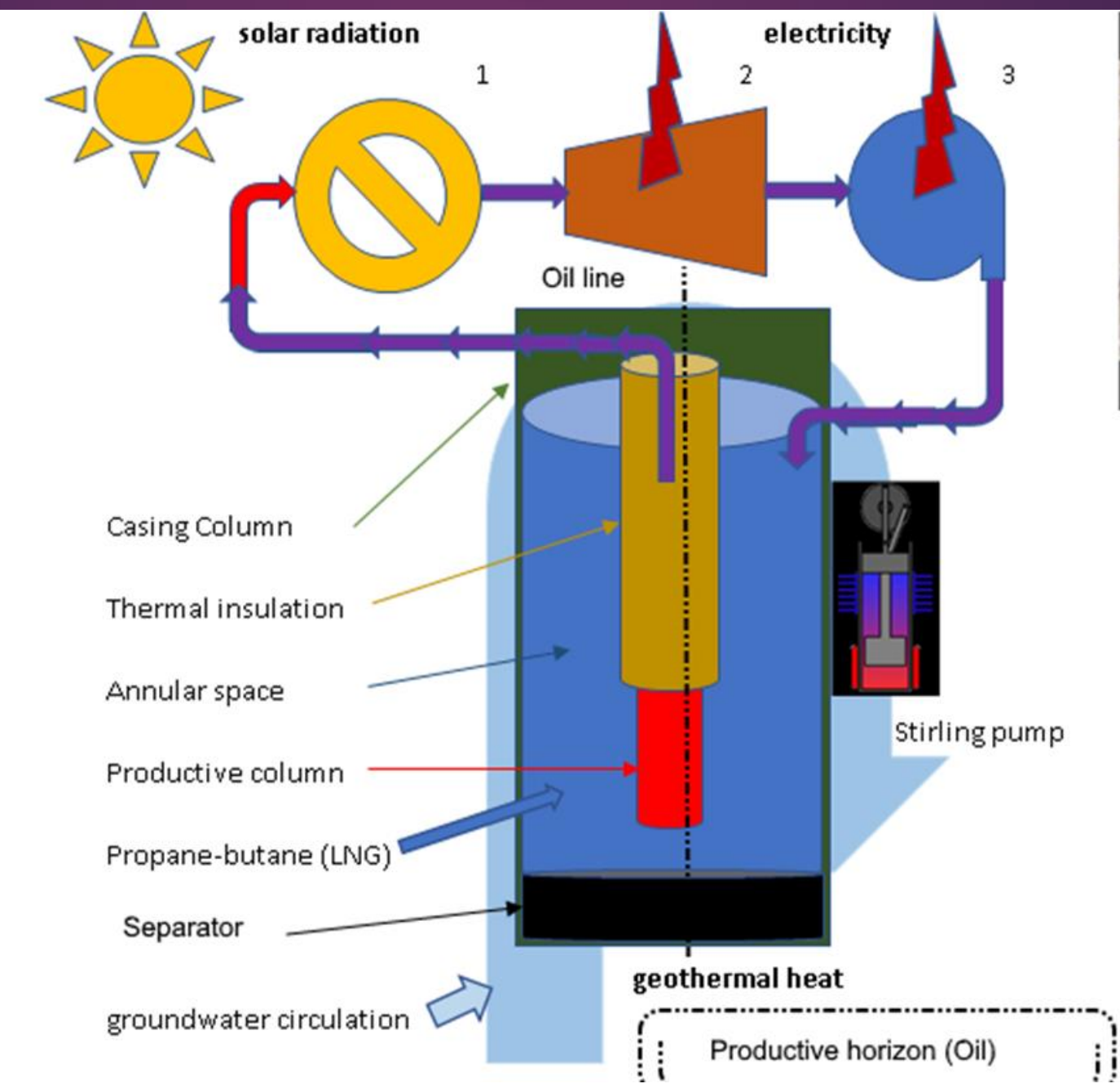

В привибійній зоні циркуАює геотермальна ріАина материнських поріА, газ та воAа віААіАяються ceпаратором. The geothermal fluid of the parent rocks circulates in the bottom zone, gas and water being separated by a separator. 


\section{3. Інтенсифрікація виАобування газу Intensification of gas production}

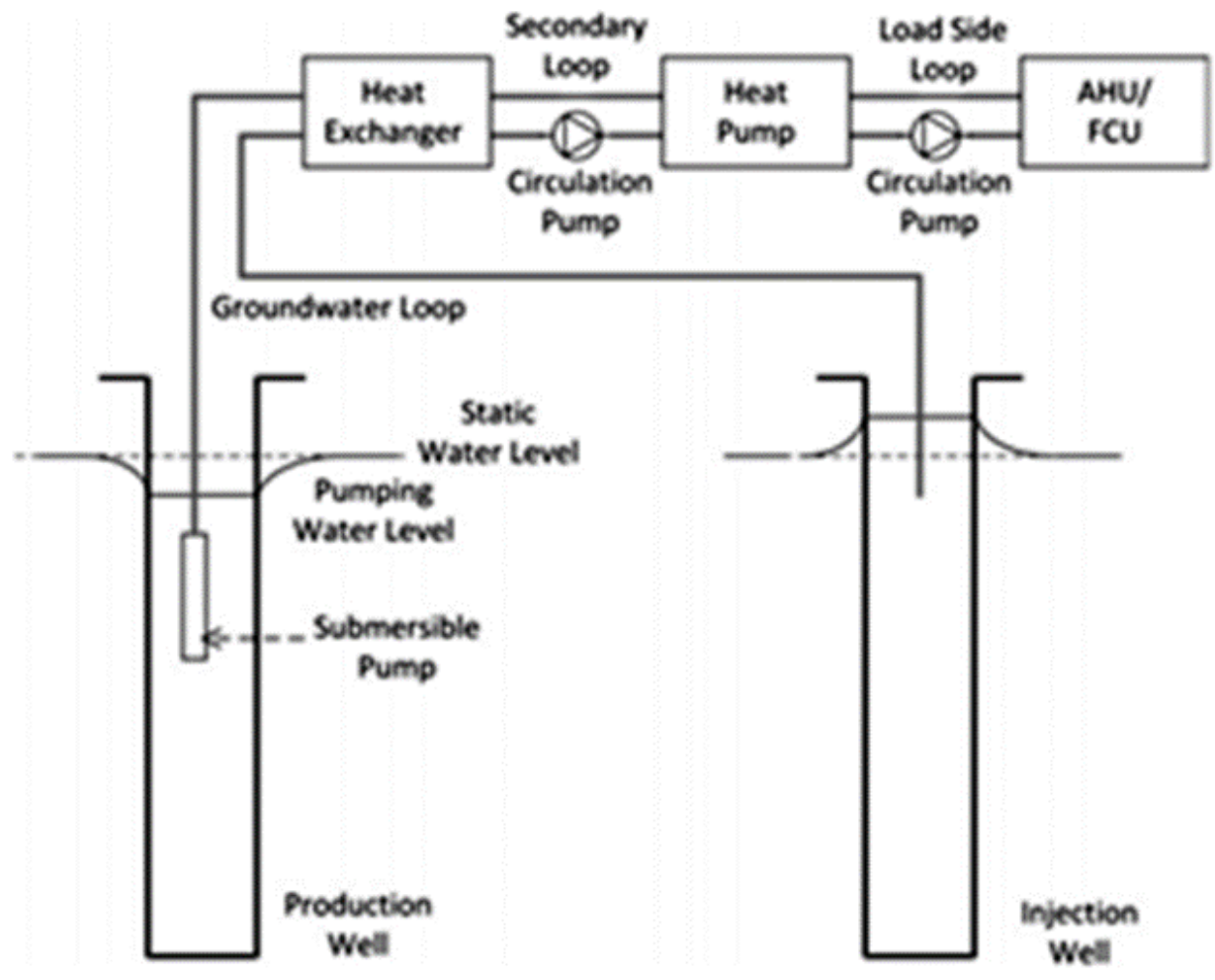

ВиАалення зайвої ріАини Removal of unnecessary fluid

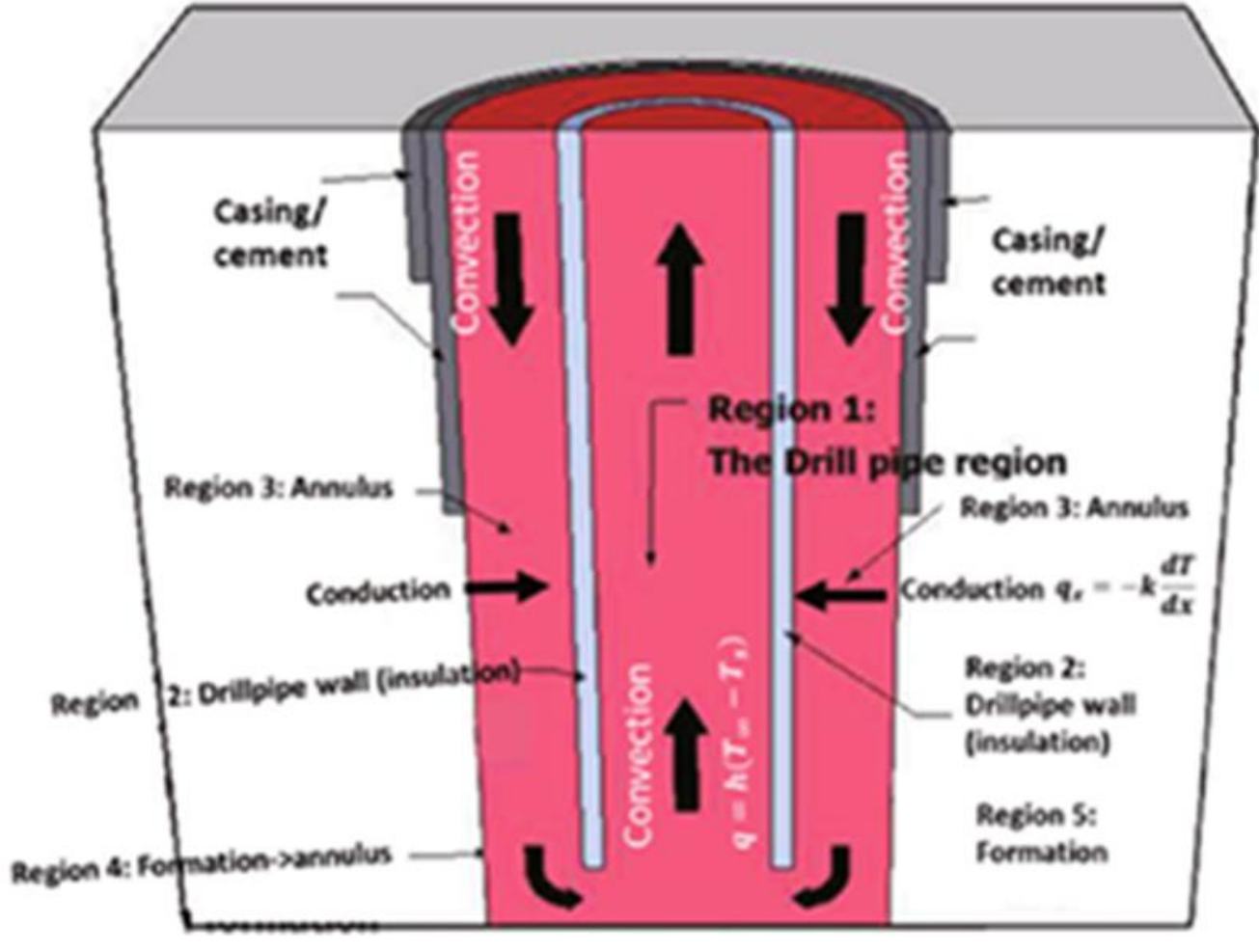

ПіАігрів колони з вологим газом Wet gas column heating 


\section{4. Інтенсиорікація видобування бітумінозних нафрт (на}

прик^аАі парогравітаційного Аренування та ППТ)
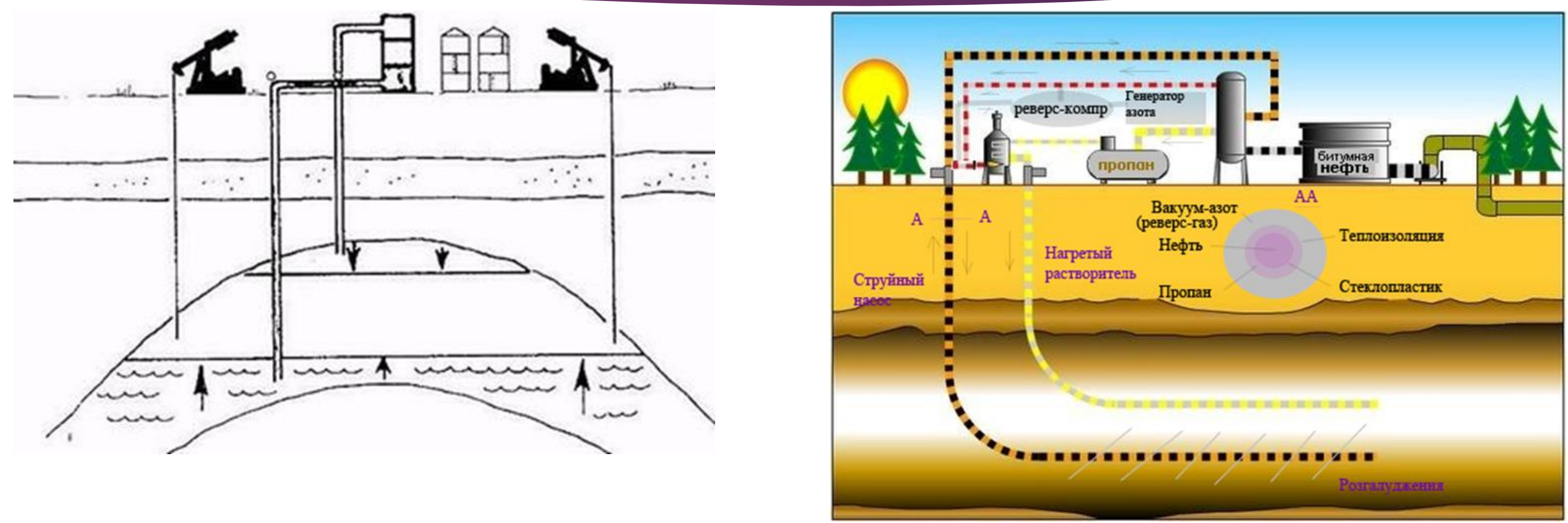

Local electricity from geothermal generators is needed to pump water and gases 
5. Организация хранения природного газа в подземных резурвуарахрегуляторах (на примере каверны)

Organization of storage of natural gas in underground reservoirs-regulators (on the

\section{example of a cavity)}

Geothermal energy in the form of local heat and electricity is needed to drive compressors, heat glycol in dehumidifiers, and cooling fans.

Геотермальна енергія у вигАяАі ^окального теп^а i електроенергії потрібна А^я привоАу компресорів, нагріву гАіколю в осушувачах, вентиляторів ОхолоАЖення.

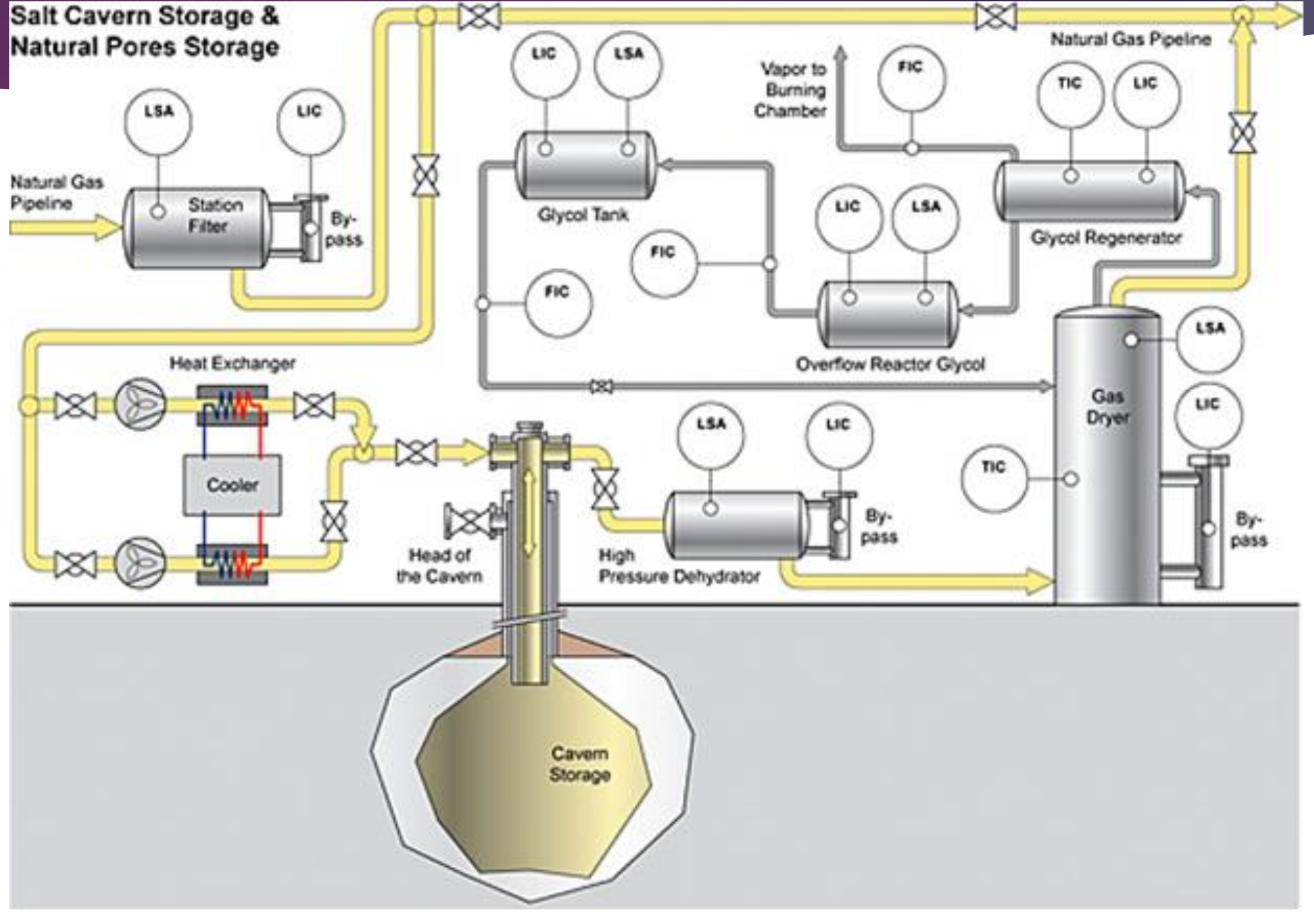




\section{3. Еволюція геометрії}

сверА^овинних теп^ообмінників Evolution of the
- The geometric topology of heat exchangers of heat pumps and geothermal systems with enclosed-type circulation through the internal heat-transfer medium. In the first row from the top, the simplest types of topologies are shown, in the bottom row - topologically more complicated: $a$ - the basic 2D-topologies; $b$ the multi-row topology modifications; $c$ - the network modifications; $d$ - the combinations of multi-row and network modifications; $\mathrm{e}$ - the frequently used complicated 2D- and 3Dtopologies.
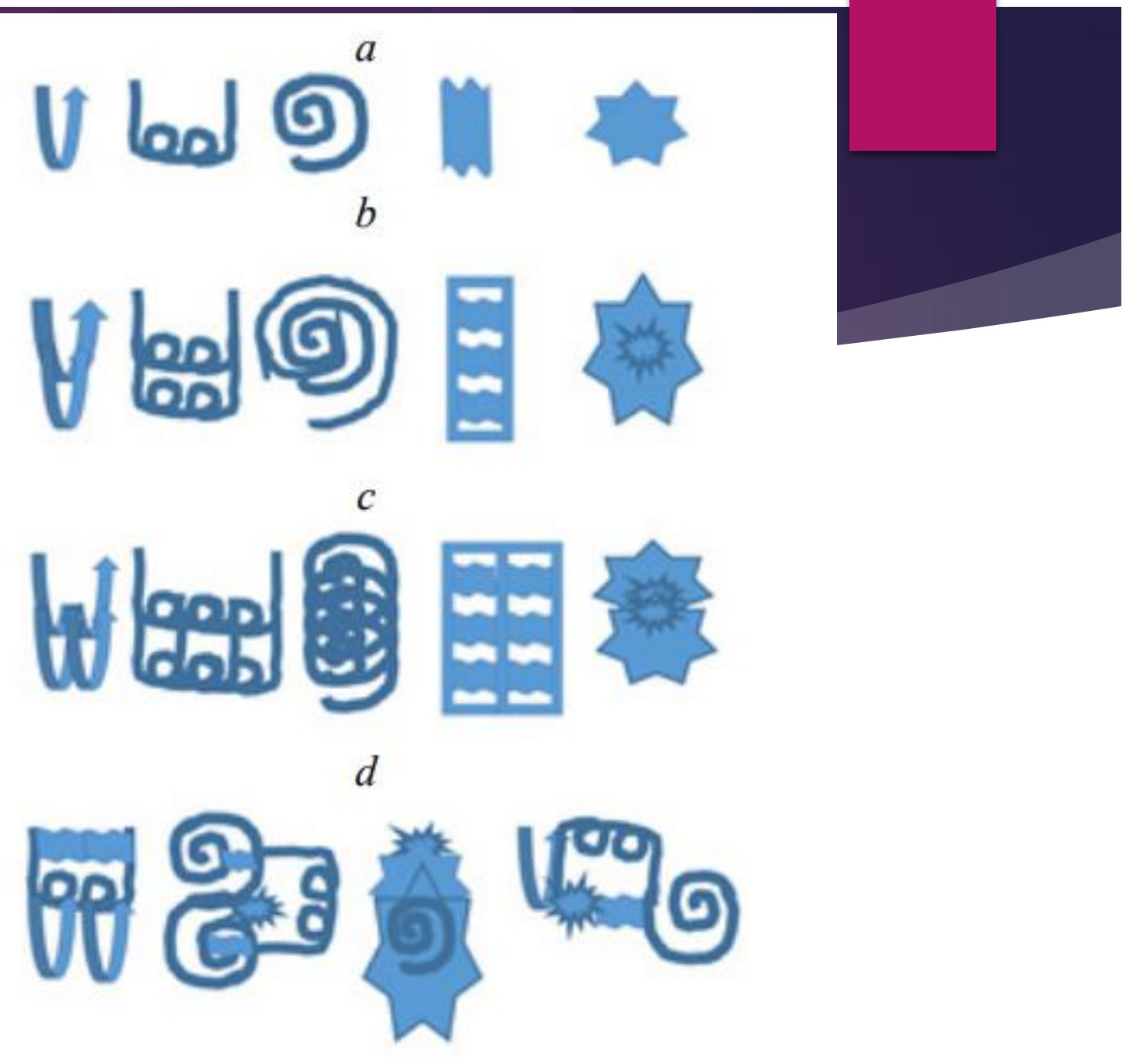

e
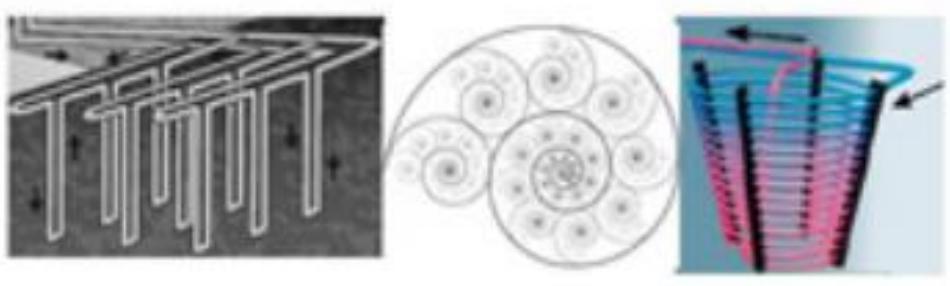


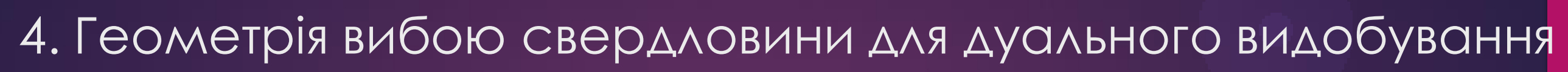
нафотогазових ффюїАів та геотермального теп^а (іАеалізована) Borehole geometry for dual production of oil and gas fluids and

\section{geothermal heof:}

1 - маніфольА із збірними колекторами; 2 - колектори; 3 - розАіл між покрівлею та ПрОАуктивним горизонтом; 4 теплосприймаючі елементи; 5 геотермальний фмюїА в ПРОАУКТИвНОМУ горизонті; 6 - піАОшва ПроАуктивноГО п^аста; 7 - притік геотермальної енергіï.

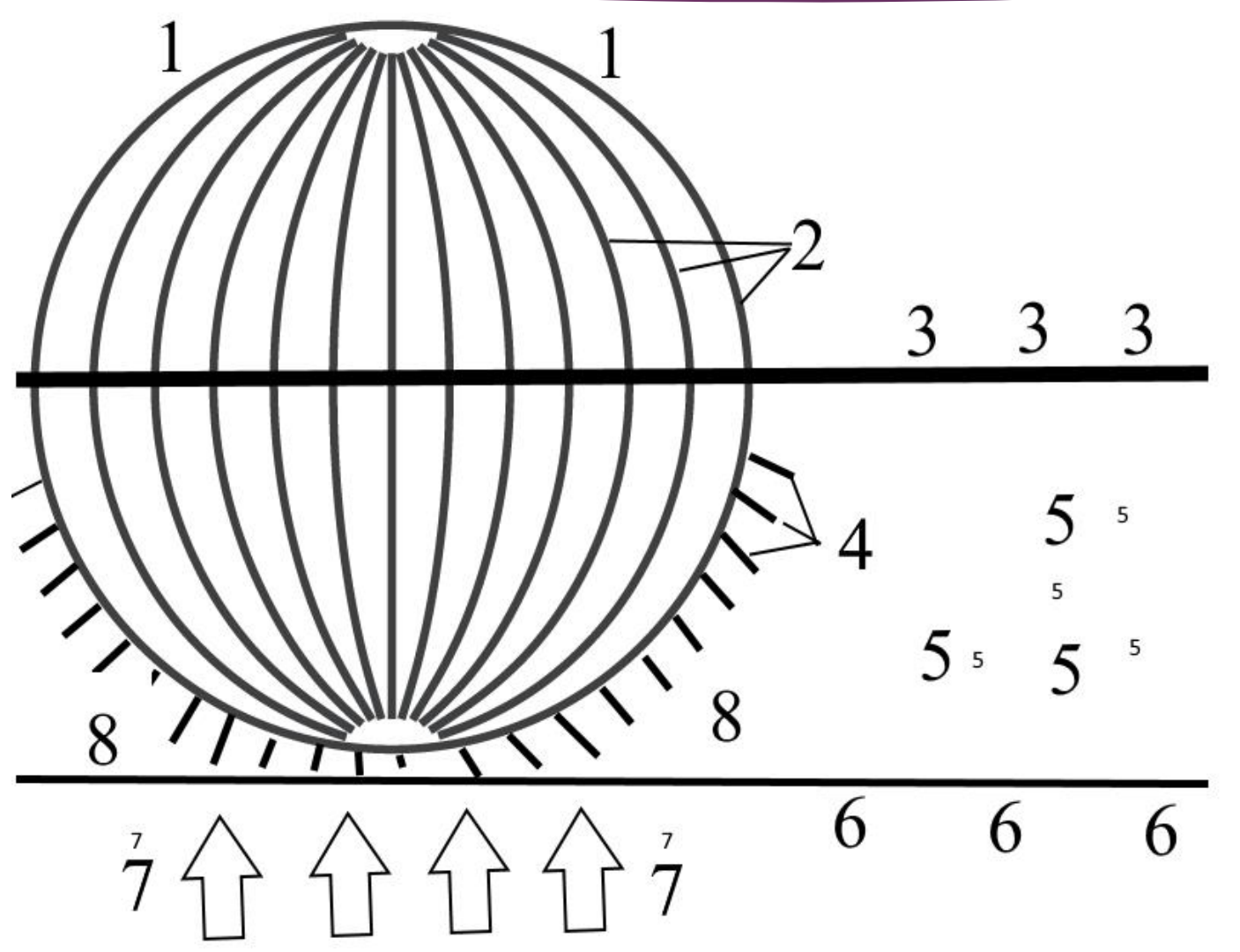

1 - manifold with precast collectors; 2 - collectors; 3 the section between the roof and the productive horizon; 4 - heat-sensing elements; 5 - geothermal fluid in the productive horizon; 6 - sole of the productive layer; 7 - inflow of geothermal energy. 


\section{Результати}

\section{Results}

- Таким чином, у запропонованій роботі нами проаналізовані варіанти геометричної реалізації геотермальних теплообмінників в нафтогазових сверАловинах при їх Ауальній експлуатації (Ітепло-фмюїА॥). При цьому переАбачено виАобування різних вуглевоАнів (нафти, газу, газового конАенсату, бітумінозних нафт) та геотермальної енергії. Запропонована іАеалізована геометрична топологія геотермального теп^ообмінника. Окремі важливі аспекти раціоналізації Ауальної експлуатації сверАловин винесено у Пункти висновків. 


\section{ВИСНОВКИ}

- 1. Аля інтенсифікації газонафтовидобутку і піАземного зберігання вуглевоАнів з оАночасним виАобутком геотермального теп^а Аоцільно облаштовувати розвинуті контури у вибійній частині із теплообмінниками, сепараторами, теплоелектрогенераторами і насосами штучної циркуляції.

- 2. ПривоАи насосів у сверАловинних піАземних контурах можуть бути тепловими Авигунами, що мають принцип роботи за циклом Стірлинга, встановлюються біля нейтральних зон температури контурів циркуяяції теплоносіїв.

- 3. ПобуАовані схеми когнітивного використання геотермальних ресурсів Аіючих нафтогазових сверАловин можуть застосовуватись піА час виАобування або зберігання як прироАних так i Синтетичних вуглевоАнів і нафтопроАуктів.

- 4. Витрати енергії на транспортування теплоносія на Аілянці вибій-гирло у випаАку використання проміжного теплоносія зменшуються на 26-41\%. Вироблена теплова та електрична енергія використовується А^я інтенсифікації сверАловин та синтезу технологічних речовин.

- 5. Геометрія вибійної частини буАується з максимальною циркуляцією материнського фмюїАу через теплообмінники Ао вторинного теплоносія або піАземних теплоелектрогенераторів. 


\section{Conclusions}

- 1. For intensific ation of gas production and underground storage of hydrocarbons with simultaneous production of geothermal heat, it is advisable to equip the developed contours in the bottomhole with heat exchangers, separators, heat generators and pumps of artificial circulation.

2. Pump drives in borehole underground circuits may be heat engines having the principle of Stirling cycle, installed near the neutral zones of the temperature of the circuits of the circulation of coolants.

- 3. The schemes for the cognitive use of geothermal resources of existing oil and gas wells can be applied during the extraction or storage of both natural and synthetic hydrocarbons and petroleum products.

- 4. Energy costs for transportation of the coolant at the well-mouth section in the case of using the intermediate coolant are reduced by 26-41\%. The heat and electrical energy produced is used for the intensification of wells and the synthesis of technological substances.

- 5. The geometry of the downhole part is constructed with the maximum circulation of the mother fluid through heat exchangers to the secondary coolant or underground heat generators. 